\title{
Intertidal facilitation and indirect effects: causes and consequences of crawling in the New Zealand cockle
}

\author{
K. N. Mouritsen ${ }^{*, * *}$ \\ Department of Marine Ecology, University of Aarhus, Finlandsgade 14, 8200 Aarhus N, Denmark \\ Portobello Marine Laboratory, Department of Marine Sciences and Department of Zoology, University of Otago, PO Box 56, \\ Dunedin, New Zealand \\ ** Present address: University of Aarhus
}

\begin{abstract}
Bioturbation by the ghost shrimp Callianassa filholi and the lugworms Abarenicola affinis as well as coverage by macroalgae cause the New Zealand cockle Austrovenus stutchburyi (Veneridae) to relocate by crawling longer distances on the sediment surface. On the surface, the cockles become targets for sublethal predation by benthic-feeding fishes, which crop off their feet. This renders the cockles unable to bury for up to $8 \mathrm{wk}$, thus exposing them to a 5 -fold higher predation pressure from shorebirds and the whelk Cominella glandiformis than buried conspecifics. Shell dimensions, foot size, general condition, gender, age, and infections by gymnophallid trematodes do not influence the crawling activity of cockles. However, heavy infection by the digenean trematode Curtuteria australis and the shell-boring spionid polychaete Boccardia acus reduces the distance travelled, and these organisms may hence reinforce the impact of the biogenic disturbers by forcing repeated crawling of the cockles to reach an undisturbed site. The presence of biogenic disturbers and some parasites therefore benefits predating fishes by providing them with an otherwise inaccessible food source, and these in turn benefit birds and whelks through foot-cropping, thus increasing the availability of prey. The gymnophallids also receive an advantage through transmission success to their definitive shorebird hosts. The question as to whether Curtuteria australis benefits, depends on the balance between its loss to fishes (unsuitable hosts) and its increased trophic transmission to its bird hosts. The spionid $B$. acus on the other hand is negatively affected, since its fate is linked to that of its substrate, which is the shell of the cockle. If the cockle is predated, the attached B. acus will perish also.
\end{abstract}

KEY WORDS: Interaction modification $\cdot$ Disturbance $\cdot$ Foot-cropping $\cdot$ Predation $\cdot$ Parasitism $\cdot$ Callianassa $\cdot$ Austrovenus $\cdot$ Soft-bottom

\section{INTRODUCTION}

Facilitation, or the positive effect one organism may have on another without itself being negatively affected, has received little attention in ecological research in comparison to, for instance, predation and competition (Bertness 1999, Stachowicz 2001). Interspecific facilitation is especially interesting because the species involved are usually integrated in a strongly interconnected community. As in the case of competitive and predator-prey relationships, facilitative interactions are therefore likely to cascade throughout a community in a series of direct and indirect positive (or negative) effects that significantly change the structure and function of the ecosystem (Stachowicz 2001, Wootton 2002). In the intertidal zone, where physical stresses or biogenic disturbances are common and the community impact of predation and competition is relaxed, facilitation may be an important albeit hitherto largely overlooked structur- 
ing force (Bertness 1999). Soft-sediment environments, for instance, can be greatly affected by bioturbation or related biogenic disturbances that significantly depress the density and number of other benthic organisms (Rhoads \& Young 1970, Brenchley 1981, Wilson 1981, Reise 1983, Suchanek 1983, DeWitt \& Levinton 1985, Posey 1986, Flach 1993, Berkenbusch et al. 2000, Bolam et al. 2000). In such habitats, facilitation processes typically involve the immigration of a disturbance-resistant organism that stabilises the substrate and thereby paves the way for a range of otherwise excluded disturbance-sensitive species (Bertness 1999 and references therein). However, while the invasion of substrate-stabilisers may benefit some species they are just as likely to be a disadvantage to others (e.g. Jones et al. 1997), and much less attention has been paid to facilitative interactions resulting from the presence of disturbers and the possible cascading direct and indirect effects they may bring about.

The ghost shrimp Callianassa filholi is common on many intertidal sandflats of Otago Harbour, New Zealand, where its substantial bioturbation activity (Fig. 1A) has been shown to depress the density and abundance of smaller infaunal organisms (Berkenbusch et al. 2000). However, C. filholi also coexists with larger macrofaunal organisms such as the New Zealand cockle Austrovenus stutchburyi (Veneridae) that may also be negatively affected by the presence of ghost shrimps. For instance, the European cockle Cerastoderma edule travels longer distances upon the sediment surface as a response to deep burial in sediment (Richardson et al. 1993), and observations of crawling tracks made by $A$. stutchburyi in association with ghost-shrimp beds or other sources of biogenic disturbance suggest that the New Zealand cockle acts in a similar manner. However, surfacing may be particularly detrimental to A. stutchburyi, because benthicfeeding fishes (Labridae) exploit this behaviour by cropping off the cockle's foot (Mouritsen \& Poulin $2003 a, b)$. This unusual kind of sublethal predation probably means that affected cockles are unable to rebury, which in turn may expose them to a higher risk of complete predation (Thomas \& Poulin 1998).

The aim of the present study was to confirm or falsify the hypothesised array of cause and effect (disturbance, surfacing, partial predation and complete predation) by (1) identifying factors affecting the surfacing behaviour of cockles taking into account also the possible impact of endogenous factors (i.e. who crawls and why?), and (2) demonstrating that surfacing results in increased partial and complete predation (i.e. what are the consequences of surface crawling?). The importance of this facilitation cascade to other members of the benthic community is discussed.

\section{MATERIALS AND METHODS}

Study area. Collections, observations and experiments were conducted during the austral summer (October to March) on Otakou and Gills Corner tidal flats, Otago Harbour, South Island, New Zealand. The macrofaunal benthic community at Otakou was dominated by ghost shrimp Callianassa filholi, cockles Austrovenus stutchburyi and mud whelks Cominella glandiformis. Ghost shrimp were rare at Gills Corner, which was characterised by a more diverse fauna, including cockles, tellinid bivalves, various species of gastropods, lugworms and other smaller polychaetes. During late summer and autumn, parts of the Gills Corner sand flat became covered by green algae, particularly Ulva lactuca. The 2 sand flats had similar sediment properties with a mean particle diameter of ca. $0.2 \mathrm{~mm}$ and a silt content of 2 to $3 \%$ (own unpubl. data). Crawling cockles were found on both flats, but in a much higher frequency at Otakou. When not stated otherwise, the following investigations were carried out at Otakou.

Sampling of crawling and buried cockles. In order to clarify whether endogenous factors (here defined as factors or conditions confined to the individual cockle) influenced the decision to crawl, samples of cockles that had been crawling $(\mathrm{n}=114)$ and remained in the sediment $(\mathrm{n}=117)$ during a preceding high tide were collected from the lower mid-intertidal. Crawling cockles were easily identified as individuals buried at the end of conspicuous crawling tracks (Fig. 1B), and noncrawling individuals were obtained by sieving sediment cores taken next to crawling tracks. The cockles were measured and dissected in the laboratory, and data on shell length, shell thickness, foot length, gender, condition factor, infection intensity by larval trematodes Curtuteria australis (infecting the foot of the cockle) and Meiogymnophallus sp. (infecting the mantle), and the presence/absence of shell damage on closing muscle scars caused by the boring polychaete Boccardia acus (Spionidae) were obtained for each individual. Because crawling is presumably an energyconsuming activity, body-size of the cockle, length/ thickness ratio (relatively slim cockles may experience less resistance during crawling than relatively thick individuals), relative size of the foot, and the cockles' general condition will probably influence the initiation and magnitude of crawling. Moreover, surfacing in other bivalves has been related to their reproductive biology (e.g. Ansell et al. 1998), suggesting that gender could be relevant, and infection by $C$. australis significantly reduces the function of the cockle's foot (Mouritsen 2002). Gymnophallids also are known to cause behavioural change in other species of bivalves (e.g. Lauckner 1983). Shell-boring polychaetes may also af- 
Fig. 1. Austrovenus stutchburyi. (A) Topographic heterogeneity of sediment surface due to bioturbation by ghost shrimp Callianassa filholi. Note presence of 2 surfaced (and footcropped) cockles. (B) Crawling tracks of cockles that have relocated after windy high-tide period had redistributed shrimp sand-mounds, making tracks particularly well defined; again, note presence of surfaced and footcropped cockle. (C) Destruction of inner shell surface of posterior muscle scars (arrows, white patches) caused by shell-boring polychaete Boccardia acus; note polychaete's excavations on outer shell-surface. (D) Surfaced cockle being attacked by mud flat whelks Cominella glandiformis. All photos are of Otakou sand flat
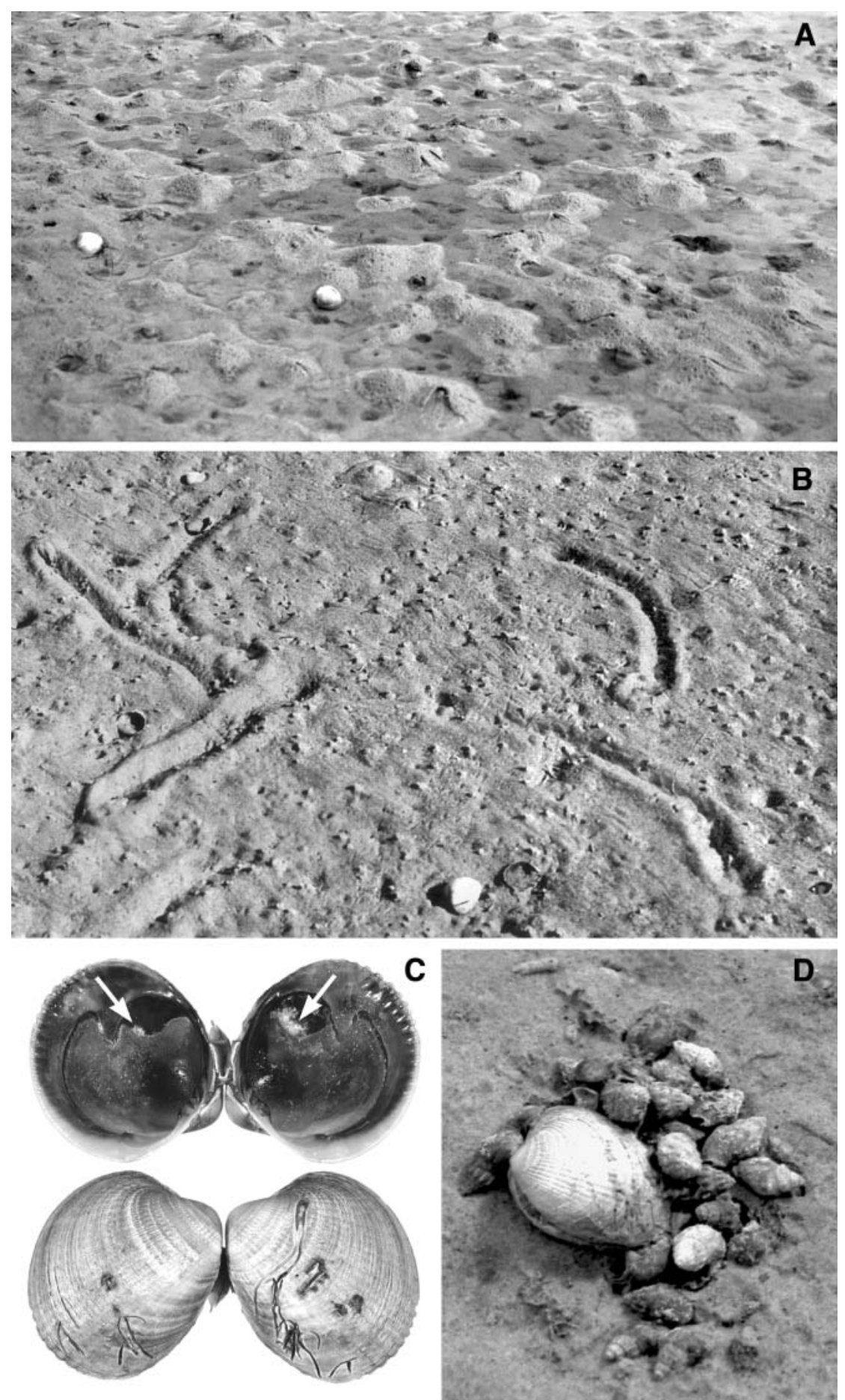

fect motoric activity, as they often undermine the attachment site (scar) of the posterior closing muscles (Fig. 1C) that participate in the action of crawling/burying (see e.g. Mouritsen 2002).

The cockles' condition factor (CF) was calculated according to the formula $\mathrm{CF}=100 \times \mathrm{STDW} / \mathrm{L}^{b}$, where STDW is soft-tissue dry weight (mg), L is shell length $(\mathrm{mm})$, and $b$ is the regression coefficient for the relationship between $\ln (\mathrm{STDW})$ and $\ln (\mathrm{L})$. This regression was statistically significant $\left(\mathrm{r}^{2}=0.99, \mathrm{df}=222\right.$, $\mathrm{p}<0.0005$ ) with a regression coefficient $b$ of 3.108 .

Repeated-crawling experiment. Cockles travel highly variable distances on the sediment surface, ranging from a few centimetres to $>1 \mathrm{~m}$. To determine whether 
crawling distance is consistent at the individual level, i.e. influenced by endogenous factors, a field experiment was carried out with 80 individually marked cockles of similar size. The cockles were buried at their natural depth along a straight line parallel to the water line in the mid-tidal zone where crawling was common. The distance between individuals was $3 \mathrm{~cm}$, and the bivalves were orientated with the anterior part in the same direction to ensure that they all moved in approximately one direction. The cockles were then left for 2 tidal cycles, after which they were recovered from the sediment and the distance between their point of release and site of recapture was measured in $10 \mathrm{~cm}$ intervals. This procedure was then repeated using the same, recaptured, cockles, and following the second recapture the cockles where brought to the laboratory for measurement and dissection. Data were obtained for the same parameters as above, and additionally their age was estimated by measuring the number of growth-interruption lines on the shell. To estimate the degree of damage by polychaetes, rather than merely recording the proportion of cockles with affected muscle scars, the actual area(s) affected by the spionids (easily identifiable as white patches on the dark, purple inner-shell surface, see Fig. 1B) were drawn in the outlines of a standard posterior closing-muscle scar traced onto graph paper. The proportion (\%) of the total scar affected could then be calculated. Condition factor was calculated as described in the preceding subsection, based on a significant $\ln (\mathrm{STDW})-\ln (\mathrm{L})$ regression $\left(\mathrm{r}^{2}=0.77, \mathrm{df}=78, \mathrm{p}<0.0005\right)$ with a regression coefficient $b$ of 2.837 .

Transect study. To determine the relationship between crawling activity and bioturbation by ghost shrimp, a $52 \times 1 \mathrm{~m}$ transect was established at the interface between a shrimp-dominated and a cockle-dominated area. The transect was parallel to the shore and was divided into 26 sections of $2 \mathrm{~m}$ each, in which mean cockle density, crawling activity and bioturbation were measured. Mean cockle density was calculated from the numbers found within 3 areas of $400 \mathrm{~cm}^{2}$ each. Crawling activity was calculated on the basis of the mean number of tracks found in each section on 8 low-tide periods evenly distributed between January and March. Bioturbation activity was calculated as the mean of 2 maximum topographic amplitude measures on the sediment surface along 2 stretches of $40 \mathrm{~cm}$ each in each section of the transect: a straight $40 \mathrm{~cm}$ stick was placed on and parallel to the surface, and the maximum distance between the lower edge of the stick and the surface was measured along the length of the stick. The sediment-processing activity of the ghost shrimp results in significant depressions at the inhalant burrow openings and sediment mounds at the exhalant openings (Jones 1983), and the topographic ampli- tude will hence provide an indirect measure of sediment turnover. In addition, 3 sediment cores, $15 \mathrm{~cm}$ deep, were taken in each section, and the depth down to which the substrate was fully oxidized (judged by colour) was recorded.

Crawling experiment on transect (Expt 1). The crawling-bioturbation relationship was also investigated experimentally. Two experiments of a design identical to that of the repeated-crawling experiment were carried out simultaneously in 2 areas of the transect dominated by ghost shrimp (significant bioturbation; see Transect Sections 15 and 16 in Fig. 2A,B) and cockles (little disturbance, Sections 21 and 22), respectively. The 60 cockles used were of similar size (mean $\pm \mathrm{SD}=32.8 \pm 2.2 \mathrm{~mm}$ ) and originated from a site between the 2 experimental areas. Bioturbation activity in terms of amplitude of the sediment surfacetopography was significantly higher in the shrimp area $(2.2 \pm 0.8 \mathrm{~cm})$ than in the cockle area $(0.5 \pm 0.2 \mathrm{~cm}$, Mann-Whitney $U$-test, $\mathrm{n}_{1}=\mathrm{n}_{2}=10, Z=3.79$, $\mathrm{p}<0.0005)$; 2 marked cockles were not recovered from the ghost-shrimp bed.

Crawling experiment on transect (Expt 2). The crawling activity of the European cockle Cerastoderma edule appears to be influenced by its own density (Richardson et al. 1993). Such intraspecific interaction could be relevant also in the New Zealand cockle, and since Expt 1 examined different parts of the transect with different cockle densities, an additional experiment was performed on a short stretch of the transect to separate the impact of shrimp and cockles on the cockles' crawling activity. Five $140 \times 140 \mathrm{~cm}$ treatment plots were established within a $280 \times 420 \mathrm{~cm}$ experimental site (see Transect Sections 13 to 15 in Fig. 2), all immediately adjacent to each other in 2 parallel rows. The first row comprised a treatment without ghost shrimp and cockles $(-\mathrm{S} /-\mathrm{C})$ and a treatment with shrimp but no cockles (+S/-C). The second row comprised a control treatment with both shrimp and cockles $(+\mathrm{S} /+\mathrm{C})$, a treatment with cockles but no shrimp $(-\mathrm{S} /+\mathrm{C})$, and an additional treatment with both shrimp and cockles in which the cockles originated from Gills Corner $\left(+\mathrm{S} /+\mathrm{C}^{*}\right)$. The latter was established to determine the effect of high infection intensities of Curtuteria australis (known to be several-fold higher at Gill Corner than at Otakou) on the cockles' crawling activity. The data obtained in the repeated-crawling experiment had suggested that these parasites might interfere with crawling activity, but that the infection levels at Otakou were probably too low to reveal a statistically significant effect (see 'Results').

Cockles present within all 5 treatment plots were removed, and ghost shrimp (which construct burrows up to $60 \mathrm{~cm}$ deep: Jones 1983) were removed from the 2 shrimp-free treatment plots by removing all sediment 
to a depth of about $80 \mathrm{~cm}$. Surface sediment from the adjacent flat was then used to refill the holes, and cockles of intermediate size were then returned (at a density of $200 \mathrm{~m}^{-2}$ ) to those plots designed to contain cockles. After 2 tidal cycles, 16 individually marked and similar-sized cockles $(30.5 \pm 1.1 \mathrm{~mm})$ were placed in a $4 \times 4$ grid within a $60 \times 60 \mathrm{~cm}$ area in the centre of each plot (nearest-neighbour distance $=20 \mathrm{~cm}$ ). This arrangement ensured that the minimum distance to non-treatment sediments was $40 \mathrm{~cm}$. After 2 additional tidal cycles, bioturbation activity was measured $(n=5)$ as previously described in each treatment plot, followed by measurements of the distance between the point of release and the point of recapture for each experimental cockle; 2 marked individuals were not recovered. The cockles were then returned to the laboratory for measurement and dissection.

Sediment addition/removal experiment. To elucidate further the relationship between ghost shrimp bioturbation and crawling activity of cockles, a $2.2 \times$ $4.2 \mathrm{~m}$ experimental site was established in an area of the flat containing no ghost shrimp. All cockles within the area were initially removed and 2250 approximately similar-sized individuals were replaced in the $1.8 \times 4.2 \mathrm{~m}$ core area (density of 298 ind. $\mathrm{m}^{-2}$ ). After 2 tidal cycles, 21 experimental plots $(20 \times 20 \mathrm{~cm}$ each $)$ separated by $40 \mathrm{~cm}$ in a $3 \times 7$ grid were marked out in the core area; and 3 different treatments were assigned at random to these plots: (1) addition of $2 \mathrm{~cm}$ sediment (+SED treatment, $n=7$ ), (2) no manipulation (control, $\mathrm{n}=7$ ), and (3) removal of sediment around the cockles leaving about half the shell exposed (-SED treatment, $n=7$ ). Care was taken not to move the buried cockles during manipulation. The number of cockles present in each -SED plot was recorded, and after 2 tidal cycles the cockles present within all 21 plots were counted.

Crawling motivation in absence of ghost shrimp. Crawling cockles can also be found on tidal flats within Otago Harbour where ghost shrimp are absent or rare, suggesting that factors other than shrimp-disturbance may induce crawling behaviour. At Gills Corner, where ghost shrimp occur only sporadically, crawling seemed to be related to a more diverse spectrum of disturbances including bioturbation (faecal mounds) by lugworms Abarenicola affinis and coverage by macroalgae and larger shells. To quantify this, the presence of larger organisms or other potential disturbances at the starting point (i.e. within a $4 \mathrm{~cm}$ deep and $4 \mathrm{~cm}$ diam. area around the starting point) of each crawling track was recorded $(n=60)$, and the frequency distribution compared with that of identified factors of disturbance on the flat in general. These were determined by throwing a cockle in the air and recording potential disturbances in the sediment at the point at which it landed (measured in the same way as the starting point data; $\mathrm{n}=125$ ). Sediment topography was also recorded $(n=21)$.

Among potential biogenic disturbers, green macroalgae and lugworms seemed especially important, and since cockles escape disturbance by crawling, it was predicted that the density of cockles below semisedentary macroalgae (i.e. those attached to shells or small stones buried in the sediment) would be lower than in adjacent uncovered substrate. To test this, the number of cockles present within $400 \mathrm{~cm}^{2}$ plots was recorded both below and adjacent to semi-sedentary green algae (mostly Ulva sp.); 35 such paired observations were made.

Foot cropping-surfacing relationship. Cockles were often found unable to bury and fully exposed on the sediment surface (Fig. 1A). Dissection of surfaced individuals revealed that their feet had been cropped. To explore the possible relationship between foot-cropping and crawling activity, during which the foot is exposed to croppers, the number of crawling tracks and surfaced cockles were recorded in 40 plots of $1 \mathrm{~m}^{2}$ along 2 parallel transects separated by $5 \mathrm{~m}$. Moreover, to clarify whether cropped cockles represent a random selection of the surfacing population, all cockles were removed from a $3 \times 3 \mathrm{~m}$ area, followed by the return of 384 individuals to the sediment surface in the central $2.25 \mathrm{~m}^{2}$ of the cockle-free area. It was expected that this would attract foot-croppers following inundation. After 2 tidal cycles, cockles that were fully exposed on the sediment surface as well as a random sample of the re-buried cockles were collected in the experimental area and returned to the laboratory for measurement and dissection. In addition to the usual parameters, data on incidence of foot cropping and the wet weight of the cockle's foot were recorded. The condition factor was obtained for footless individuals, based on a significant $\ln (\mathrm{STDW})-\ln (\mathrm{L})$ regression $\left(\mathrm{r}^{2}=0.91, \mathrm{df}=46\right.$, $\mathrm{p}<0.0005$ ) with a regression coefficient $b$ of 2.687 .

Foot-regeneration experiment. Cockles that have been cropped are unable to bury until the foot is sufficiently regenerated. To determine the time required for this, 25 newly cropped cockles (obtained as above) were placed in a mesh cage (mesh size $=2 \times 2 \mathrm{~cm}$ ) at the study site. At fairly regular intervals, those caged cockles that were buried were returned to the sediment surface and the number still visible after 2 tidal cycles was recorded. Monitoring continued until all cockles had regained full burying ability. The cockles were then dissected and the proportion of foot showing tissue-regeneration and the proportion initially cropped (regenerated tissue + tissue still missing) were determined. Regenerated foot-tissue was easily distinguished from old tissue by its whitish appearance, and the proportion of the foot initially cropped was estimated on the basis of the extrapolated projected foot-area obtained according to Mouritsen \& Poulin 
(2003a). All experimental cockles had been cropped, and on average 30\% (range 9 to $100 \%$ ) of the foot had been lost. On average, $70 \%$ (range 29 to $100 \%$ ) of the lost tissue had regenerated at the point of dissection.

Predation experiment. In the study area, 2 significant groups of cocklepredators were frequently encountered: oystercatchers Haematopus ostralegus finschi and $H$. unicolor and mud flat whelks Cominella glandiformis. Since these predators readily attack surfaced cockles (Thomas \& Poulin 1998, Ansell 2001; and present Fig. 1D), an experiment was conducted to clarify whether surfaced, and hence foot-cropped, cockles are more susceptible to bird and/or whelk predation than buried specimens. Two $1 \mathrm{~m}^{2}$ plots were established $15 \mathrm{~m}$ apart in an area of the flat where ghost shrimp were uncommon and birds often seen feeding. The plots were fenced by $2 \times$ $2 \mathrm{~cm}$ mesh, with $4 \mathrm{~cm}$ above and $10 \mathrm{~cm}$ below the sediment surface. The fence was intended to keep surrounding and enclosed cockles as well as shells separated and yet allow birds and whelks to enter. The 2 areas were cleared of cockles and largersized cockle-shells to a depth of approx. $15 \mathrm{~cm}$. Cockles of intermediate size were then returned to the sediment surface of the enclosures and cockles still present on the surface after 2 tidal cycles were marked. Additional experimentally obtained footcropped and marked cockles were added to the enclosures so that a total of 665 buried and 52 surfaced cockles were enclosed. After $4 \mathrm{wk}$, the number of marked and unmarked cockles and shells found within a depth of $\sim 10 \mathrm{~cm}$ was recorded in each enclosure.

Statistical analysis. All analyses were carried out using SPSS (Statistical Package of Social Sciences). Standard parametric tests were preceded by test for assumptions and, when violated, the data were either transformed or non-parametric statistics were applied. Percentage data were arcsine-transformed if any values approached zero or $100 \%$.

\section{RESULTS}

\section{Who crawls?}

Cockles that had been crawling and cockles that had remained buried during a preceding high tide could not be distinguished by parameters measured
(Table 1). The only parameters showing some numerical difference between groups were gymnophallid intensity (higher in crawling cockles) and frequency of attack by the boring polychaete Boccardia acus (higher in non-crawling cockles). But neither of these differences was statistically significant (Table 1).

The repeated-crawling experiment indicated that endogenous factors apparently do not influence the cockle's decision to crawl. There were no differences in properties between consistently non-crawling cockles and cockles that crawled in at least 1 of the 2 trials (Table 2: All cockles). Moreover, although the proportion of cockles that did not crawl was similar in both trials $($ Trial $1=35.0 \%$; Trial $2=41.3 \%$; total $=38.1 \%$; Fisher's exact test, $\mathrm{p}=0.25$ ), their proportion was generally not made up of the same individuals: only $16.3 \%$ of cockles did not crawl in either trial, which corresponds well with the $14.5 \%$ non-crawling cockles $\left(100 \times 0.381^{2}\right)$ expected were the decision to crawl or not crawl distributed randomly among individuals in each trial. Among cockles that crawled in both trials, there was no significant correlation between the distances travelled in the 2 trials $(r=0.17$, df $=30, p=$ 0.33), indicating that overall there was no consistency in the distance travelled by individual cockles. Nevertheless, among the few cockles that consistently crawled a short, intermediate or long distance in both trials, there was a significant negative relationship between distance travelled and the relative area of the muscle scars affected by polychaete attack, and a sim- 
Table 2. Austrovenus stutchburyi. Repeated crawling experiment: characteristics of cockles not crawling in either trial, crawling in at least 1 trial, and crawling a similar distance in both trials. Values are mean (SD) or median [interquartile range] where not indicated otherwise. Statistical test on foot length, trematode intensity (Curtuteria australis and Meiogymnophallus sp.; no. of metacercariae per cockle) and polychaete attack (Boccardia acus) was carried out on data corrected for cockle size, and for polychaete attack also on arcsine-transformed percentages. Note that polychaete attack measure differs from that in Table 1, here denoting proportion of combined area of 2 posterior muscle scars affected (see 'Materials and methods'). Relative dimension: Shell length/thickness ratio

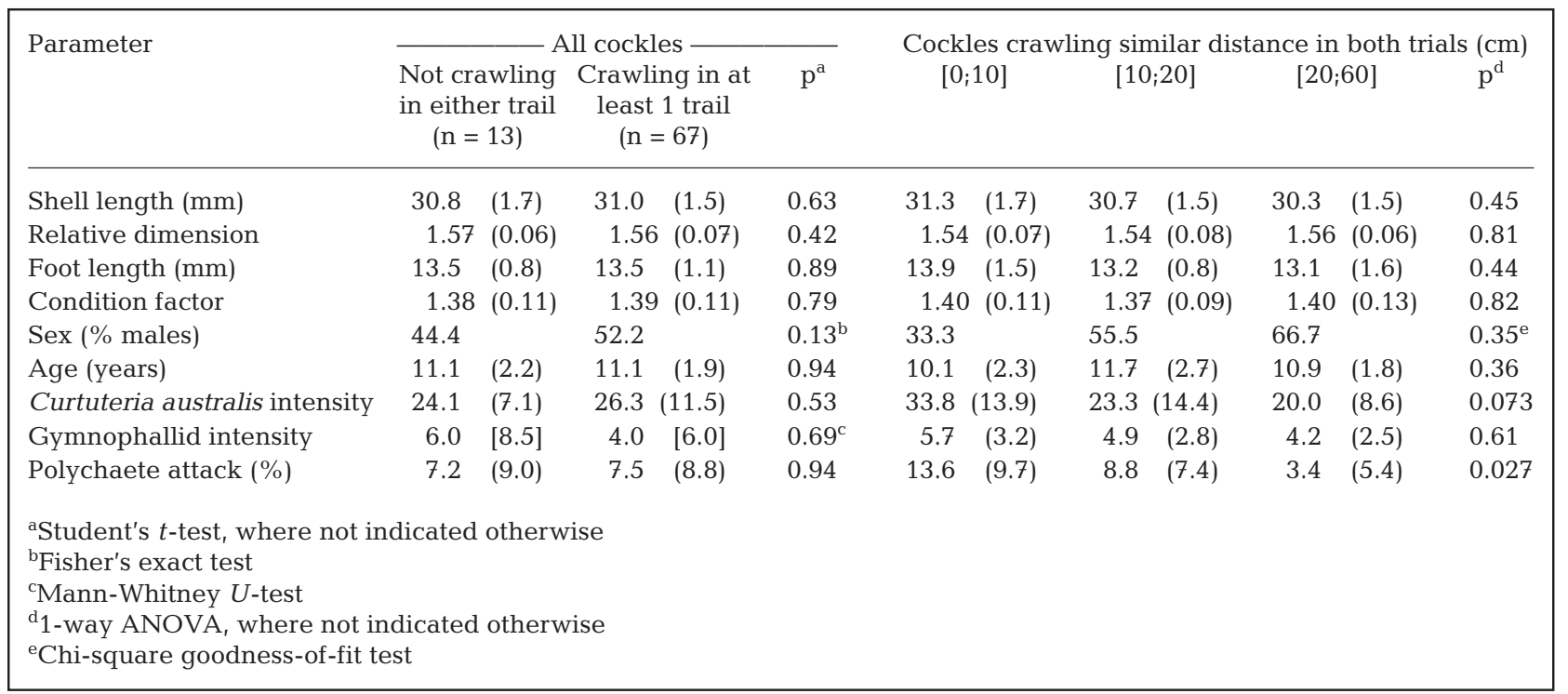

ilar tendency in respect to Curtuteria australis intensity (Table 2). Multiple regression analysis revealed that polychaete attack and $C$. australis intensity together explained $23.3 \%$ of the variation in distances travelled in both trials combined $\left(F_{2,29}=4.40, \mathrm{p}=0.021\right)$.

\section{Why do cockles crawl?}

Cockles and ghost shrimp (in terms of bioturbation activity) had complementary distributions along the transect, and crawling tracks of cockles were found mainly in fully oxidised and strongly bioturbated sediment (Fig. 2). Hence, there was a strong positive relationship between cockle crawling activity and ghost shrimp disturbance (Fig. 3). This significant relationship persisted $\left(r^{2}=0.33, d f=16, p=0.013\right)$ when only transect sections with significant bioturbation (Sections 1 to 18 , see Fig. 2A,B) were considered. A residual analysis controlling for the effect of bioturbation showed that cockle density (between 50 and $216 \mathrm{~m}^{-2}$ ) had no effect on crawling activity $\left(\mathrm{r}^{2}=0.01, \mathrm{p}=0.69\right)$.

The positive relationship between crawling and bioturbation was further demonstrated by the transect experiments (Expts 1 and 2). The patterns of crawling activity in the 2 areas dominated by cockles and ghost shrimp respectively (Expt 1) were significantly different (Kolmogorov-Smirnov test, $Z=1.59, \mathrm{p}=0.013$; Fig. 4): in the ghost-shrimp bed more cockles moved and those that did, travelled longer distances. Similar results were obtained from the 5-treatment experiment (Expt 2) evaluating the combined effect of shrimp and cockles on cockle crawling activity (Fig. 5). Significantly more cockles moved in the Otakou-cockle treatments with ghost shrimp $(22.6 \%)$ than in treatments without shrimp (3.2\%, Fisher's exact test, $\mathrm{p}=0.029)$, and the average distance travelled was about 3 -fold larger in the presence than in the absence of ghost shrimp, irrespective of presence or absence of residential cockles (Fig. 5). Moreover, the crawling activity of the more heavily infected Gills Corner cockles was substantially lower (ca. one-third) than that of the lightly infected Otakou cockles (Fig. 5: $+\mathrm{S} /+\mathrm{C}$ vs $+\mathrm{S} /+\mathrm{C}^{*}$ treatments), suggesting that Curtuteria australis strongly interferes with the cockles' mobility. Experimental cockles did not differ significantly between treatments in regard to shell dimensions, sex ratio, age, relative foot weight and gymnophallid intensity (data not shown, various tests, $\mathrm{p}>0.10$ ). C. australis intensity was similar among Otakou-cockle treatments (grand mean $\pm \mathrm{SD}=26.2 \pm$ 9.9; 1 -way ANOVA, $F_{3,59}=1.36, \mathrm{p}=0.27$ ) which, as expected, was significantly less than parasite intensity in the Gills Corner cockles in the $+\mathrm{S} /+\mathrm{C}^{*}$ treatment $(133.4 \pm 57.1$; Bonferroni tests, $\mathrm{p}<0.0005$ for all relevant comparisons). Topographical heterogeneity of the sediment surface differed significantly among treatments (1-way ANOVA, $\left.F_{4,20}=17.4, \mathrm{p}<0.0005\right)$ : the 2 treatments without ghost shrimp had a common low 
topographical heterogeneity of $0.5 \mathrm{~cm}$ as opposed to the 2.1 to $2.4 \mathrm{~cm}$ found (on average) in ghost-shrimp treatments (Bonferroni tests, $\mathrm{p}<0.001$ ). This demonstrates that the experimental design succeeded in achieving treatments with different levels of bioturbation.

Although the above experiment (Expt 2) involved pseudo-replication, the possibility that the results were influenced by non-treatment factors can be excluded.
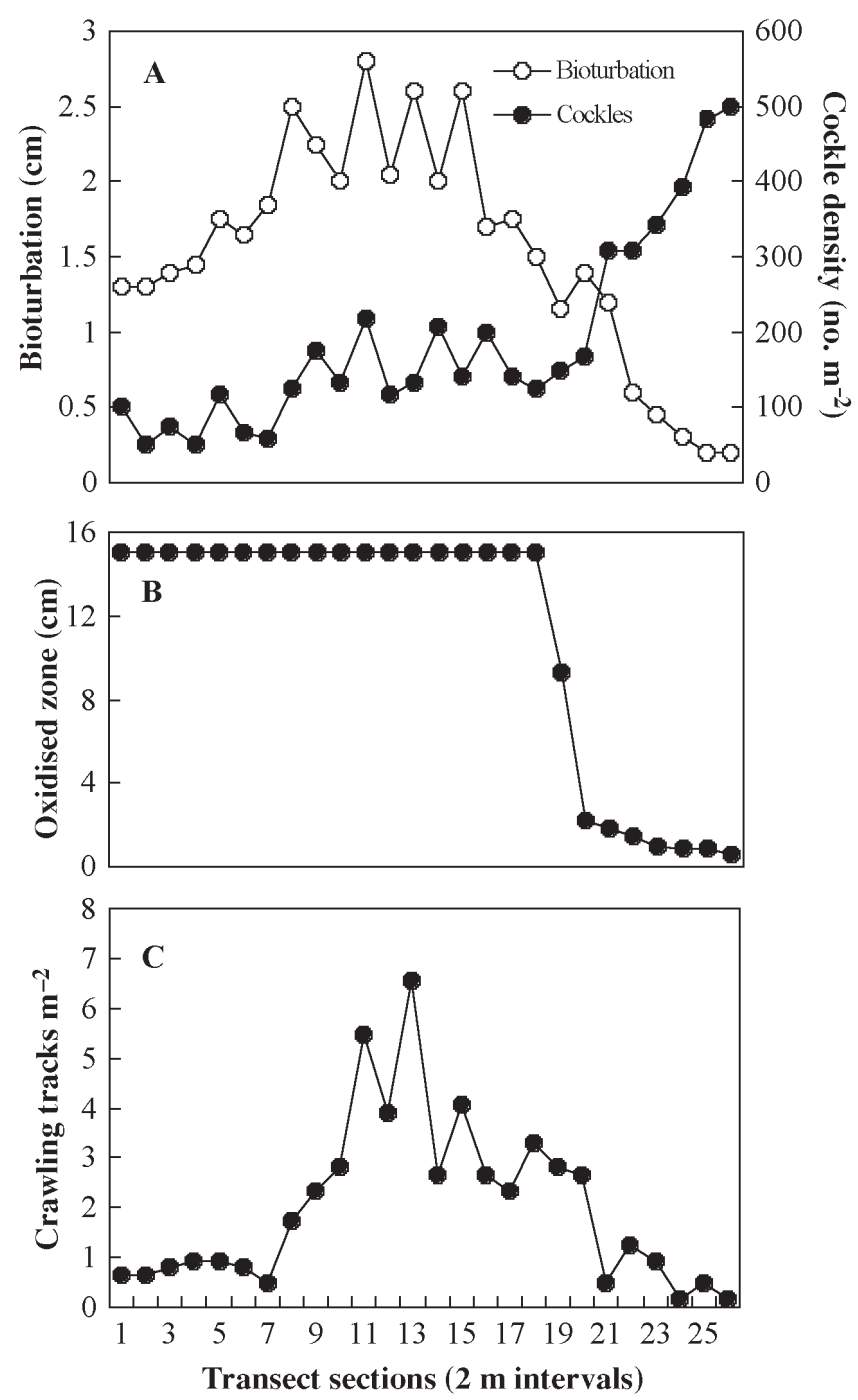

Fig. 2. Bioturbation activity of ghost shrimp Callianassa filholi, sediment properties, density of cockle Austrovenus stutchburyi and their crawling tracks on $56 \mathrm{~m}$ long transect (divided into $2 \mathrm{~m}$ sections) across a ghost-shrimp bed and a cockle bed on Otakou sand flat. Error estimates associated with mean values omitted for sake of simplicity. (A) Mean maximum topographic amplitude of sediment surface (bioturbation, $\mathrm{n}=$ 2 per section) and mean cockle density ( $\mathrm{n}=3$ per section). (B) Depth to which substrate was fully oxidised in $15 \mathrm{~cm}$ sediment cores $(\mathrm{n}=3$ per section); maximum values $(15 \mathrm{~cm})$ indicate fully oxidised sediment to at least this depth. (C) Mean density of crawling tracks of cockles $(n=8)$
Firstly, the experiment was carried out under unusually calm weather conditions, allowing any disturbance of the treatment plots to be readily identified on the sediment surface, with no disturbances being seen except the expected ghost-shrimp bioturbation and crawling tracks of the cockles. Secondly, the influence of significant abiotic gradients can be excluded because of the close clustering of treatments (within a couple of metres). I nevertheless refrained from carrying out a formal 2-way ANOVA using each experimental cockle as a replicate. Instead, by using the mean crawling distance of cockles in each treatment plot as

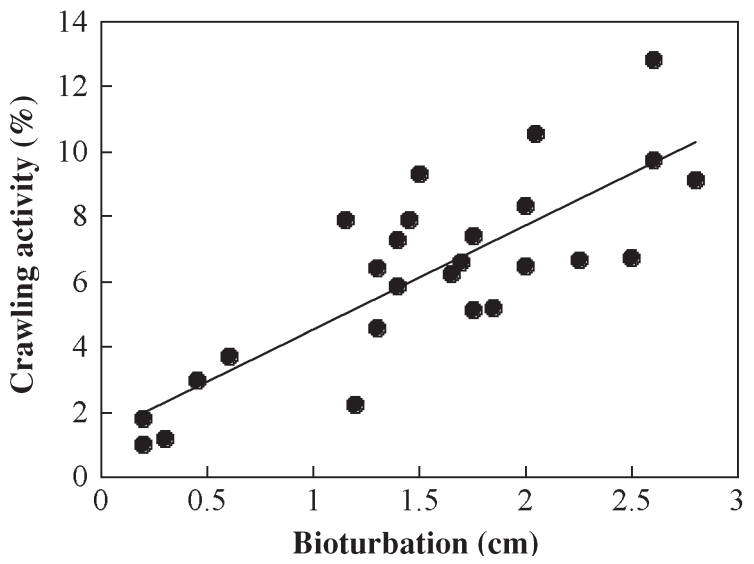

Fig. 3. Austrovenus stutchburyi. Relationship between mean crawling activity (arcsine-transformed percent of cockles crawling) and bioturbation activity (mean maximum topographic amplitude on sediment surface) of ghost shrimp Callianassa filholi along transect at Otakou sand flat (see Fig. 2). Positive relationship is statistically significant $\left(\mathrm{r}^{2}=0.65\right.$, $\mathrm{df}=24, \mathrm{p}<0.0005)$

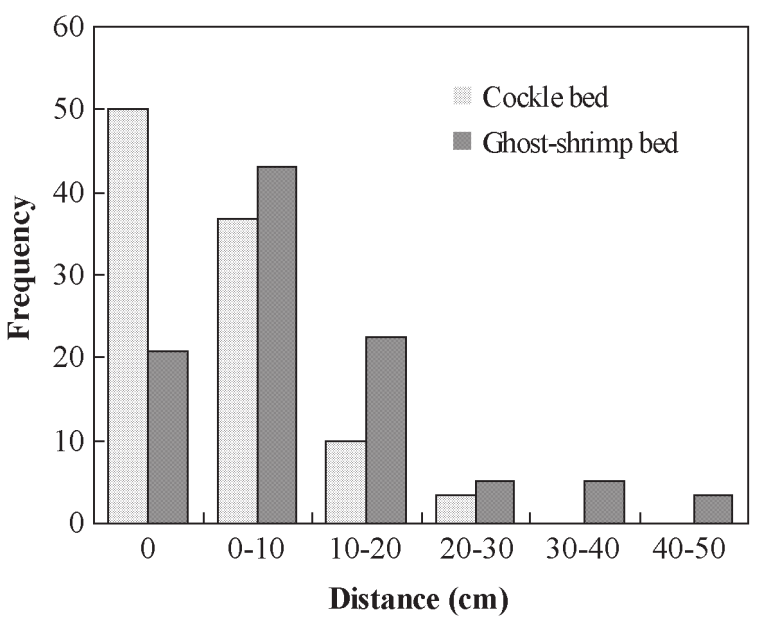

Fig. 4. Austrovenus stutchburyi. Distance travelled during 2 tidal cycles by cockles experimentally placed in littledisturbed cockle bed $(n=60)$ and in ghost-shrimp bed with strong bioturbation activity $(\mathrm{n}=58)$ 
the unit of analysis, a statistically sound experimental design was achieved comprising $\mathrm{a}+\mathrm{S}$ and $\mathrm{a}-\mathrm{S}$ treatment replicated twice (Otakou cockles only). Analysis of these data showed (not surprisingly) a significantly higher mean crawling activity in the presence than in absence of ghost shrimp irrespective of the presence or absence of non-experimental cockles (Student's $t$-test with separate variance estimate, $t_{1.92}=9.23, \mathrm{p}=0.013$ ).

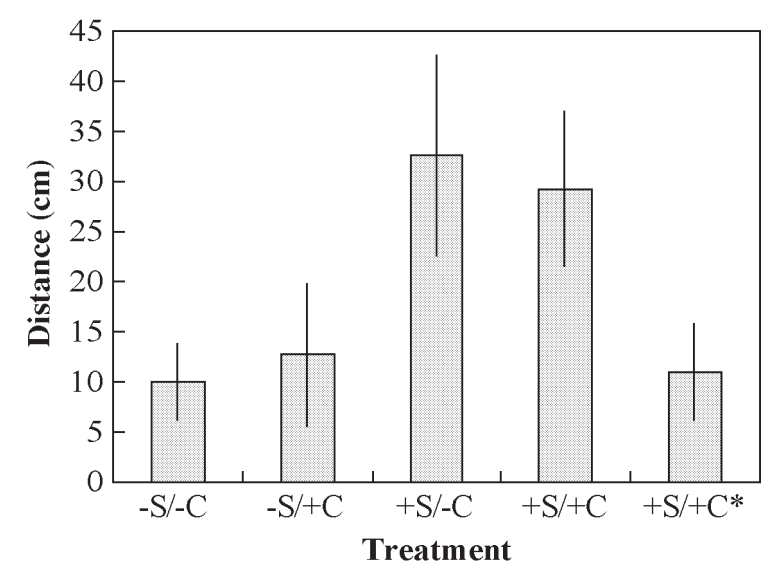

Fig. 5. Austrovenus stutchburyi. Mean distance travelled ( $\pm 95 \% \mathrm{CL}$ ) during 2 tidal cycles by experimental cockles exposed to different levels and sources of disturbance. $-\mathrm{S} /-\mathrm{C}$ : ghost shrimp Callianassa filholi and resident cockles removed $_{i}-\mathrm{S} /+\mathrm{C}$ : shrimp removed, resident cockles present (200 ind. $\left.\mathrm{m}^{-2}\right)_{i}+\mathrm{S} /-\mathrm{C}$ : shrimp present, resident cockles removed $+\mathrm{S} /+\mathrm{C}$ : shrimp and cockles $\left(200\right.$ ind. $\left.\mathrm{m}^{-2}\right)$ present (control) $i+\mathrm{S} /+\mathrm{C}^{*}$ : shrimp and cockles $\left(200\right.$ ind. $\mathrm{m}^{-2}$ ) present, experimental cockles heavily infected by Curtuteria australis. $(\mathrm{n}=16$ except for control and $-\mathrm{S} /+\mathrm{C}$ treatment, where $\mathrm{n}=15)$

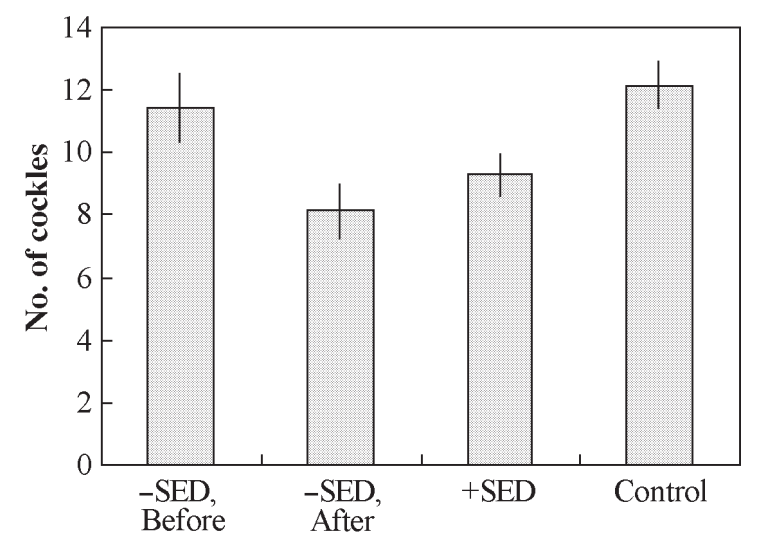

Treatment

Fig. 6. Austrovenus stutchburyi. Mean number of cockles ( \pm SE) found after 2 tidal cycles in $20 \times 20 \mathrm{~cm}$ plots manipulated by removal and addition of sediment. -SED: sediment removed, causing residing cockles to be half-exposed (Before, After: counts of cockles before and after experiment); +SED: addition of extra sediment layer; Control: untreated plots ( $\mathrm{n}=7$ for all values)
The sediment addition/removal experiment attempting to simulate ghost shrimp disturbance showed that both addition and removal of sediment influenced the crawling activity of cockles. Significantly fewer cockles were found after than prior to the experiment in plots where sediment had been removed (-SED treatments, paired $t$-test, $t_{6}=4.07, \mathrm{p}=0.007$; Fig. 6). Moreover, the number of cockles recovered from each of the 3 treatments at the end of the experiment differed significantly (1-way ANOVA, $F_{2,18}=7.31, \mathrm{p}=0.005$ ). Post hoc Bonferroni tests revealed significantly fewer cockles in both -SED and +SED plots than in the controls $(p=0.005$ and 0.049 , respectively), whereas the impact of the 2 different sediment treatments was similar $(p=0.91)$. This demonstrates that cockles exposed to disturbance in terms of both addition and removal of sediment tend to relocate rather than adjusting their vertical position in the substrate.

At Gills Corner, ghost shrimp were uncommon and the sediment surface was hence substantially less disturbed (maximum topographic amplitude $=0.4 \pm$ $0.2 \mathrm{SD} \mathrm{cm} ;$ cf. Fig. 2A). The frequency distribution of other potential disturbances connected with crawling tracks and with the flat in general was significantly different (chi-square contingency test, $\chi^{2}{ }_{4}=58.26$, p $<0.0005$, Fig. 7; Macomona shells and whelks were grouped in the analysis because of the low numbers of counts). In particular, macroalgae coverage and bioturbation by lugworms was associated with crawling by

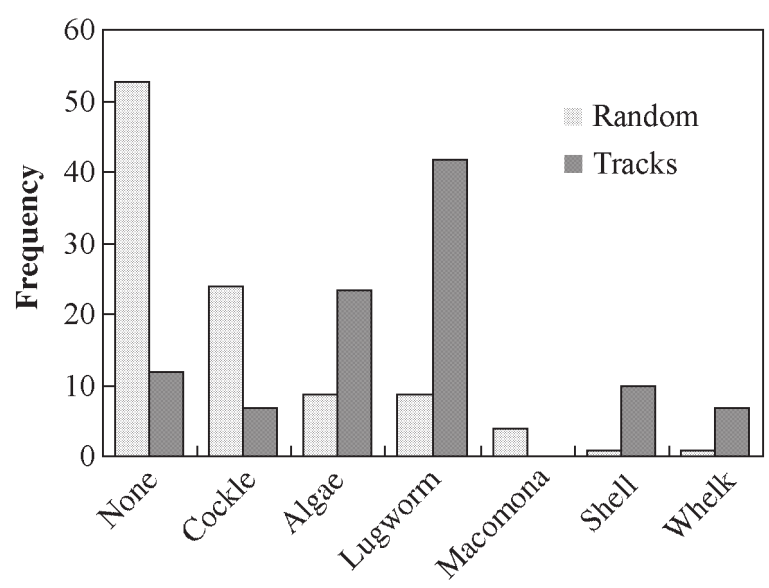

Fig. 7. Austrovenus stutchburyi. Frequency distribution of disturbances inducing potential crawling on Gills Corner sand flat. Tracks: disturbances at starting point of crawling tracks $(\mathrm{n}=60)$; Random: overall frequency distribution of identified disturbances on flat $(n=125)$. None: no obvious disturbing factor identified; Cockle: A. stutchburyi in sediment; Algae: macroalgae (particularly Ulvae sp.) on sediment surface; Lugworm: faecal mound produced by Abarenicola assimilis; Macomona: tellinid bivalve Macomona liliana in sediment; Shell: any species of larger shell on surface; Whelk: predatory mud whelk Cominella glandiformis in sediment 


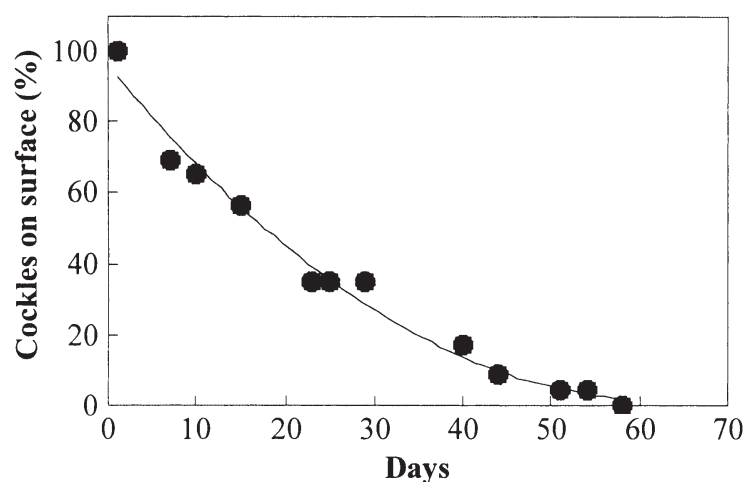

Fig. 8. Austrovenus stutchburyi. Proportion of caged, footcropped cockles unable to bury as a function of time $(n=23)$. Trend line represents fitted second-order Taylor polynomial

cockles, but also empty shell coverage and the proximity of predatory whelks seemed to have some effect. The importance of macroalgae is clearly demonstrated by the significantly lower cockle density in the area covered by semistationary macroalgae $(5.7 \pm 2.2 \mathrm{SD}$ $\left.400 \mathrm{~cm}^{-2}\right)$ than in adjacent sediment $(7.8 \pm 2.6$; paired $t$-test, $\left.t_{34}=3.56, \mathrm{p}=0.001\right)$, suggesting that affected cockles tend to relocate.

\section{What are the consequences of crawling?}

The number of cockles lying fully exposed on the sediment surface of the transects (see 'Foot croppingsurfacing relationships') correlated significantly with the density of crawling tracks $(\mathrm{r}=0.78$, $\mathrm{df}=38, \mathrm{p}<0.0005)$, suggesting $\mathrm{a}$ causal relationship. Moreover, of the 384 cockles experimentally placed on the sediment surface, $6.8 \%$ were unable to rebury after 2 tidal cycles. All but 1 of the surfaced individuals had been foot-cropped, whereas less than half $(42 \%)$ of the re-buried specimens had been cropped (Table 3). The foot damage to the foot-cropped, buried cockles was generally lighter and had largely regenerated, suggesting insubstantial or 'old' damage. Moreover, the foot weigth was less and infection intensity of Curtuteria australis was lower in surfaced than in burrowed cockles (Table 3). This may be the direct consequence of cropping. The metacercarial cysts of $C$. australis occur mainly in the tip of the cockle foot, which also is the part most often cropped (Mouritsen 2001, Mouritsen \&
Poulin 2003a). Otherwise, buried and surfaced cockles could not be separated by the parameters measured (Table 3), suggesting that the cropping risk is equal among surfacing cockles.

The foot-regeneration experiment showed that footcropped cockles are usually confined to the sediment surface for a prolonged period of time. A period of about 8 wk was necessary for all newly cropped and caged cockles to regain their ability to bury ( 2 died during the experiment), and 18 d elapsed until $50 \%$ buried (Fig. 8). During this period, surfaced cockles were exposed to a higher predation risk than buried conspecifics. At the termination of the predation experiment, $19 \%$ of the foot-cropped cockles were still visible on the sediment surface, and overall the mortality rate in the surfaced population was more than 5 -fold higher than in burrowed cockles in the 2 experimental plots combined (continuity-corrected chisquare goodness-of-fit test, $\chi^{2}{ }_{1}=12.71, \mathrm{p}=0.002$, Fig. 9). Because oystercatchers very often move seized cockles to a firm substrate for handling (e.g. patches of sea grass bed; own pers. obs.), and because whelk predation always leaves shell remains, the presence of empty shells within the experimental plots (predation experiment) suggested whelk predation, whereas the absence of empty shells suggested bird predation. Based on this assumption, predation from shorebirds and whelks contributed more or less evenly to the mortality in both surfaced and buried cockles (Fig. 9).

Bioturbation-mediated relocation of cockles appeared also to increase small-scale spatial heterogeneity in cockle density (see Fig. 2A). Based on the coeffi-

Table 3. Austrovenus stutchburyi. Characteristics of cockles buried in sediment (random sample, $n=26$ ) and lying exposed on surface $(n=24) 2$ tidal cycles after forced exposure of 384 cockles. Values are mean (SD) or median [interquartile range] where not indicated otherwise. Statistical test on foot weight and infection intensity by Curtuteria australis and Meiogymnophallus sp. (no. of metacercariae per cockle) was carried out on data corrected for cockle size. Polychaete attack measured as proportion of combined area of 2 posterior muscle scars affected, and foot-cropping as proportion of cockles cropped

\begin{tabular}{|lclrlc|}
\hline Parameter & \multicolumn{2}{c}{ Buried } & \multicolumn{2}{c|}{ On surface } & $\mathrm{p}$ \\
\hline Shell length (mm) & 34.3 & $(3.8)$ & 33.5 & $(3.8)$ & $0.47^{\mathrm{a}}$ \\
Foot weight (mg) & 75.7 & $(25.1)$ & 54.4 & $(19.7)$ & $<0.0005^{\mathrm{a}}$ \\
Condition factor & 2.07 & $(0.60)$ & 2.06 & $(0.18)$ & $0.91^{\mathrm{a}}$ \\
Sex (\% males) & 37.5 & & 40.9 & & $0.71^{\mathrm{b}}$ \\
Age (yr) & 14.0 & $(4.1)$ & 13.7 & $(3.7)$ & $0.81^{\mathrm{a}}$ \\
Foot cropping (\%) & 42.3 & & 91.7 & & $<0.0005^{\mathrm{b}}$ \\
Curtuteria australis intensity & 34.0 & {$[21.5]$} & 13.0 & {$[26.3]$} & $0.001^{\mathrm{c}}$ \\
Gymnophallid intensity & 6.0 & {$[5.0]$} & 5.0 & {$[5.0]$} & $0.98^{\mathrm{c}}$ \\
Polychaete attack (\%) & 3.3 & {$[11.0]$} & 5.8 & {$[12.1]$} & $0.41^{\mathrm{c}}$ \\
& & & & & \\
a'Student's $t$-test & & & & & \\
bFisher's exact test & & & & & \\
'Mann-Whitney $U$-test & & & & & \\
\hline
\end{tabular}




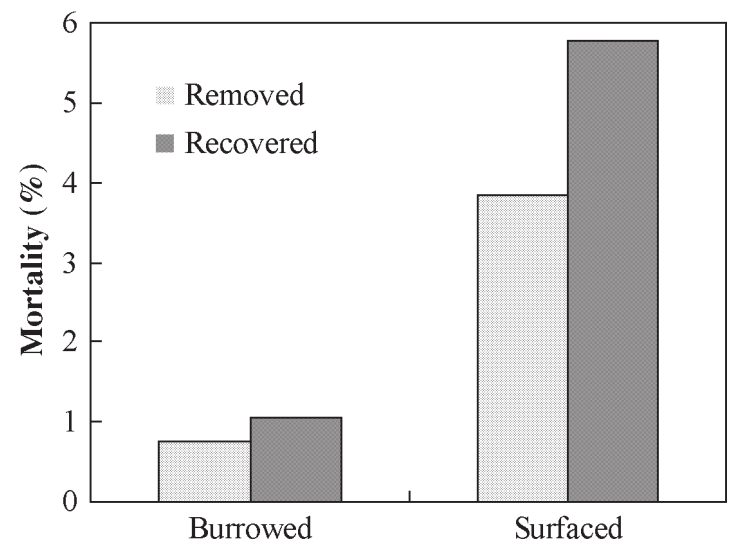

Fig. 9. Austrovenus stutchburyi. Mortality rate of cockles buried in sediment (Burrowed, $\mathrm{n}=665$ ) and foot-cropped cockles initially lying fully exposed on sediment surface (Surfaced, $\mathrm{n}=52$ ) during $4 \mathrm{wk}$ period. Removed: cockles not recovered from experimental sites and assumed predated by shorebirds; Recovered: cockles found as empty shells in experimental sites and assumed predated by whelk Cominella glandiformis

cients of variation $(\mathrm{CV}=100 \mathrm{~s} / \mathrm{x})$ for each of the 26 transect sections, the average CV was significantly (2-fold) higher in the heavily disturbed $(49.7 \%$; Sections 4 to 18) than in the less disturbed area $(24.8 \%$; remaining sections, Student's $t$-test, $t_{24}=2.48, \mathrm{p}=0.020$ ).

\section{DISCUSSION}

The results indicate that cockles crawl at random, since none of the measured endogenous parameters influenced the cockles' decision to crawl or not to crawl. However, 3 lines of evidence, combined, indicated that bioturbation by the ghost shrimp Callianassa filholi is an important factor motivating cockles to move, the causative mechanisms apparently being undermining of the cockles' dwelling substrate in the vicinity of the shrimp's inhalant burrow-opening, and burial of the cockles in expelled sediment at the exhalant opening. The substrate in such areas is continuously disturbed, forcing resident cockles to repeatedly adjust their vertical position. Escaping such unconsolidated sediments through surface crawling would therfore seem to be an adaptive behaviour. Richardson et al. (1993) observed a similar response in the European cockle Cerastoderma edule experimentally exposed to burial, and suggested that crawling could be a widespread escape-behaviour of short-siphoned suspension-feeding bivalves living in habitats where the upper sediment stratum is regularly disturbed (see also Ansell 1994). The exact nature of the disturbance appears less important, since bioturbation by lug- worms Abarenicola affinis, coverage by macroalgae and to some extent also by shells, and even the vicinity of the mud whelk Cominella glandiformis can also induce crawling behaviour similar to that induced by ghost-shrimp bioturbation. Richardson et al. (1993) also showed that surfacing activity of $C$. edule is positively influenced by the presence of conspecifics, in that crawling individuals induce surfacing in buried specimens they encounter along their path. Such intraspecific interaction could not be demonstrated in the present study, however, whith the crawling activity of Austrovenus stutchburyi being unaffected by cockle densities of $>200$ ind. $\mathrm{m}^{-2}$.

Not only do ghost shrimp induce crawling in cockles, they also increase significantly the distance travelled. The cockle's foot is in continuous contact with the substrate during crawling, and the cockle may be able to recognise the stability of the substrate over which it passes. Because a cockle moves to escape unconsolidated sediment, it may keep crawling until a sufficiently stable site is reached. In a ghost-shrimp bed with significant bioturbation activity, such refugia will be rare and restricted to narrow patches between shrimp burrow-openings; thus finding consolidated sediment by chance will obviously take longer within than outside ghost-shrimp beds. This also predicts a higher small-scale spatial heterogeneity in cockle density inside than outside ghost-shrimp-dominated areas, because the cockles will tend to accumulate in scattered patches of undisturbed substrate. This prediction is confirmed by the transect data from the ghostshrimp-dominated Otakou flat. However, sources of disturbance other than bioturbation may also produce spatial heterogeneity in cockle density, as evidenced by the significantly higher density adjacent to than below macroalgae at Gills Corner.

Siphon-nipping by various benthic-feeding fishes is widespread in soft-bottom bivalves, and Austrovenus stutchburyi is no exception (Whitlatch et al. 1997, Mouritsen \& Poulin 2003a and references therein). The main consequence for the bivalves is loss of stored energy necessary for the regeneration process, and for long-siphoned, deeper-buried species, it also means a shallower burying depth, which in tidal areas may increase the predation pressure from shorebirds (Goeij et al. 2001). The fact that biogenic disturbance induces substantial surfacing activity in the New Zealand cockle is particularly critical as it may cause benthic feeding fishes to shift their focus from relatively benign siphon-nipping to more detrimental foot-cropping. The latter strongly facilitates predation by both shorebirds and whelks by forcing cropped bivalves to stay fully exposed on the sediment surface for an extended period of time. Thus, in the absence of biogenic disturbers, the cockle population will be exposed to a certain level of 


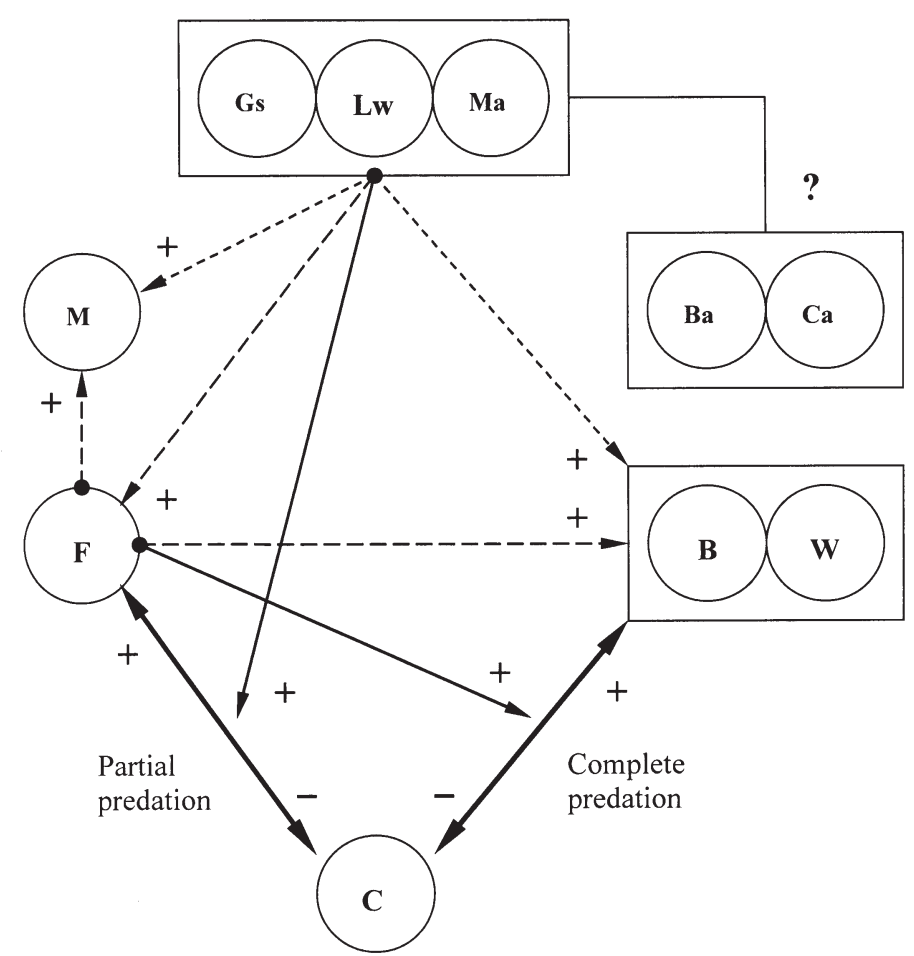

Fig. 10. Network of direct and indirect interspecific interactions. Organisms involved are grouped into 4 functional groups (rows). From bottom: cockle Austrovenus stutchburyi $(\mathrm{C})$, predators $(\mathrm{F}, \mathrm{B}, \mathrm{W})$, parasites $(\mathrm{M}$, $\mathrm{Ba}, \mathrm{Ca}$ ), and biogenic disturbers (Gs, Lw, Ma). Cockles are related to shorebirds (B) and whelks Cominella glandiformis $(\mathrm{W})$ through complete predation and to benthic feeding fishes $(\mathrm{F})$ through partial predation $(-/+$, thick arrows). The biogenic disturbers, ghost shrimp Callianassa filholi (Gs), lugworms Abarenicola affinis (Lw) and macroalgae (Ma), facilitate partial predation by foot-cropping fishes, which in turn facilitates complete predation (interaction modification) $(+$, thin arrows). Biogenic disturbers will consequently have an indirect positive effect $(+$, broken arrows) on benthic feeding fishes and through these on birds and whelks also. Thus, disturbers have negative effect on the cockles. Since transmission success of trematode Meiogymnophallus sp. (M) to the definitive shorebird host will increase with increasing level of complete predation, biogenic disturbers and fishes will have an indirect positive effect on this parasite. Question mark at the connection between the biogenic-disturber box and box containing shell-boring polychaete Boccardia acus (Ba) and trematode Curtuteria australis $(\mathrm{Ca})$ indicates that position and function of these parasites in the system is unclear, but probably resembles that of biogenic disturbers. See 'Discussion' complete predation by birds and whelks, and partial predation by fishes, probably directed mainly at the cockles' siphons. However, in the presence of biogenic disturbers, these trophic interactions become integrated in a more complex network of facilitation processes: the biogenic disturbers will facilitate partial predation by exposing the cockles' feet to croppers, which in turn will facilitate complete predation by birds and whelks. Hence, biogenic disturbers have an indirect positive effect on benthic fishes, which may consequently have a higher feeding success (interaction modification), and the fishes will have an indirect positive effect on birds and whelks for the same reason. Consequently, biogenic disturbers will, through this interaction chain, also indirectly benefit birds and whelks. These interactions are summarised in Fig. 10, which also includes relationships with the system's parasites, the shell-boring polychaete Boccardia acus and the trematodes Curtuteria australis and Meiogymnophallus sp. The role of these parasites and their relationship to the remaining organisms in the network is intriguing, although to some extent also more uncertain. Since both $B$. acus and $C$. australis reduce the travelling distance of the cockles, they may interfere with their host's attempt to reach consolidated substrate during crawling events. This could force the more heavily infected hosts into repeated crawling before a refuge from disturbance can be reached, and hence expose them to a higher cropping risk. If so, the function of the parasites resembles that of the biogenic disturbers (indicated by the the connecting line between disturber-box and parasite-box in Fig. 10). Moreover, $B$. acus uses the shell of the cockle as a substrate for its burrow, and if the cockle host is predated, then the attached polychaetes are likely to perish, since the empty shell will be beached or buried deeply beneath the sediment surface. Foot-cropping fishes will thus affect the polychaetes negatively, whereas the biogenic disturbers will do this in an indirect manner. C. australis will also be affected by the presence of both disturbers and fishes. This trematode uses oystercatchers as its definitive host, which is reached by trophic transmission (Allison 1979); because predation pressure on surfaced cockles is higher than on buried cockles, the combined effect of disturbers and croppers would, at first glance, seem to benefit the parasite. However, because these parasites encyst in the foot of the cockle, they will also be exposed to direct predation from footcropping fishes, and since fishes are unsuitable hosts, the parasites they consume will be lost. How C. australis is affected at the population level will depend on the trade-off between the increased transmission rate to shorebirds and the loss to fishes (see Mouritsen \& Poulin 2003b). Interestingly, Meiogymnophallus sp. is the only parasite to receive a clear-cut advantage from the facilitation processes. It uses shorebirds as definitive hosts, just as C. australis (Lauckner 1983), but since it does not infect the foot of the cockle, it will have a significantly higher transmission success in the presence of disturbers and foot-croppers (Fig. 10). 
Biogenic disturbance is known to directly impact the structure of soft-bottom animal communities. For the ghost shrimp Callianassa filholi, this has recently been demonstrated in Otago Harbour, where its bioturbation activity tends to reduce both the number and the density of smaller infaunal species (Berkenbush et al. 2000). However, this shrimp appears to reduce the density of larger community members such as Austrovenus stutchburyi also, either through facilitation of complete predation or by repeatedly inducing cockles to move until they eventually leave the ghost-shrimp beds. Both these processes may have contributed to the more or less complementary distribution of cockles and shrimp on Otakou sand flat (Fig. 2A). In addition, the shrimp also seem to increase the small-scale spatial heterogeneity in cockle density. Because, through a range of processes such as sediment disturbance/stabilisation, filtration activity and pseudofaeces production, cockles themselves modify the surrounding animal community (Flach 1996, Whitlatch et al. 1997), the impact of ghost shrimp or functionally similar biogenic disturbers may extend much further than a direct effect on the benthic community in their immediate vicinity by modulating the density and spatial distribution of cockles. Moreover, Thomas et al. (1998) have shown that the relative abundance of the common epifaunal mudflat anemone Anthopleura aureoradiata and the estuarine limpet Notoacmea helmsi is significantly different on surfaced than on buried cockles, indicating that disturbance-facilitated foot-cropping activity alone can affect community structures. Possibly in most soft-bottom habitats, cascades of direct and indirect effects initiated by biogenic disturbers (and sometimes enhanced by parasites) significantly affect a wide range of functionally and taxonomically different organisms, thereby changing the structure and function of the zoobenthic community. Our understanding of this will not be complete until such cascades of facilitation processes receive more attention.

Acknowledgements. The work was supported by grants from the Carlsberg Foundation, The Danish Natural Science Research Council (both Denmark) and the Marsden Foundation (New Zealand). I also wish to thank Robert Poulin and referees for constructive comments on an earlier draft, Keith Probert, Department of Marine Sciences, for providing information on the benthic intertidal community of Otago Harbour whenever needed, and the staff of Portobello Marine Laboratory for invaluable technical support.

\section{LITERATURE CITED}

Allison FR (1979) Life cycle of Curtuteria australis n. sp. (Digenea: Echinostomatidae: Himasthlinae), intestinal parasite of the South Island pied oystercatcher. N Z J Zool 6:13-20

Ansell AD (1994) In situ activity of the sandy beach bivalve Donax vittatus (Bivalvia Donacidae) in relation to potential predation risks. Ethol Ecol Evol 6:53-53

Ansell AD (2001) Dynamics of aggregations of a gastropod predator/scavenger on a New Zealand harbour beach. J Molluscan Stud 67:329-341

Ansell AD, Günther CP, Burrows MT (1998) Partial emergence of the bivalve Donax vittatus in response to abrupt changes in light intensity and before spawning. J Mar Biol Assoc UK 78:669-672

Berkenbusch K, Rowden AA, Probert K (2000) Temporal and spatial variation in macrofauna community composition imposed by ghost shrimps Callianassa filholi bioturbation. Mar Ecol Prog Ser 192:249-257

Bertness MD (1999) The ecology of Atlantic shorelines. Sinauer Associates, Sunderland, MA

Bolam SG, Fernandes TF, Read P, Raffaelli D (2000) Effects of macroalgal mats on intertidal sandflats: an experimental study. J Exp Mar Biol Ecol 249:123-137

Brenchley GA (1981) Disturbance and community structure: an experimental study of bioturbation in marine soft-bottom environments. J Mar Res 39:767-790

DeWitt TH, Levinton JS (1985) Disturbance, emigration, and refugia: how the mud snail, Ilyanassa obsoleta (Say), affects the habitat distribution of an epifaunal amphipod, Microdeutopus gryllotalpa (Costa). J Exp Mar Biol Ecol 92: 97-113

Flach EC (1993) The distribution of the amphipod Corophium arenarium in the Dutch Wadden Sea: relationships with sediment composition and the presence of cockles and lugworms. Neth J Sea Res 31:281-290

Flach EC (1996) The influence of the cockle, Cerastoderma edule, on the macrozoobenthic community of tidal flats in the Wadden Sea. Mar Ecol 17:87-98

Goeij P de, Luttikhuisen PC, van der Meer J, Piersma T (2001) Facilitation on an intertidal mudflat: the effect of siphon nipping by flatfish on burying depth of the bivalve $\mathrm{Ma}$ coma balthica. Oecologia 126:500-506

Jones CG, Lawton JH, Shachak M (1997) Positive and negative effects of organisms as physical ecosystem engineers. Ecology 78:1946-1957

Jones MB (1983) Animals of the estuary shore. University of Canterbury, Christchurch, New Zealand

Lauckner G (1983) Diseases of Mollusca: Bivalvia. In: Kinne O (ed) Diseases of marine animals, Vol. 2. Biologische Anstalt Helgoland, Hamburg, p 477-961

Mouritsen KN (2002) The parasite-induced surfacing behaviour in the cockle Austrovenus stutchburyi: a test of an alternative hypothesis and identification of potential mechanisms. Parasitology 124:521-528

Mouritsen KN, Poulin R (2003a) The risk of being at the top: foot-cropping in the New Zealand cockle Austrovenus stutchburyi. J Mar Biol Assoc UK 83:497-498

Mouritsen KN, Poulin R (2003b) Parasite-induced trophic facilitation exploited by a non-host predator: a manipulator's nightmare. Int J Parasitol 33:1043-1050

Posey MH (1986) Changes in a benthic community associated with dense beds of a burrowing deposit feeder, Callianassa californiensis. Mar Ecol Prog Ser 31:15-22

Reise K (1983) Sewage, green algal mats anchored by lugworms, and the effects on turbellaria and small polychaeta. Helgol Wiss Meeresunters 36:151-347

Rhoads DC, Young DK (1970) The influence of depositfeeding organisms on sediment stability and community trophic structure. J Mar Res 28:150-178

Richardson CA, Ibarrola I, Ingham RJ (1993) Emergence pattern and spatial distribution of the common cockle Cerastoderma edule. Mar Ecol Prog Ser 99:71-81

Stachowicz JJ (2001) Mutualism, facilitation, and the struc- 
ture of ecological communities. BioScience 51:235-246

Suchanek TH (1983) Control of seagrass communities and sediment distribution by Callianassa (Crustacea, Thalassinidea) bioturbation. J Mar Res 41:281-298

Thomas F, Poulin R (1998) Manipulation of a mollusc by a trophically transmitted parasite: convergent evolution or phylogenetic inheritance? Parasitology 116:431-436

Thomas F, Renaud F, de Meeûs T, Poulin R (1998) Manipulation of host behaviour by parasites: ecosystem engineering in the intertidal zone? Proc R Soc Lond B 265:1091-1096

Editorial responsibility: Otto Kinne (Editor),

Oldendorf/Luhe, Germany
Whitlatch RB, Hines AH, Trush SF, Hewitt JE, Cummings V (1997) Benthic faunal responses to variation in patch density and patch size of a suspension-feeding bivalve. J Exp Mar Ecol Biol 216:171-189

Wilson WH Jr (1981) Sediment-mediated interactions in a densely populated infaunal assemblage: the effects of the polychaete Abarenicola pacifica. J Mar Res 39:735-748

Wootton JT (2002) Indirect effects in complex ecosyatems: recent progress and future challenges. J Sea Res 48: $157-172$

Submitted: December 2, 2002; Accepted: October 14, 2003 Proofs received from author(s): April 5, 2004 